\title{
The Age of Criminal Responsibility from the Perspective of Malaysian Shariah Law
}

\author{
Wafaa’ Binti Yusof ${ }^{1} \&$ Anita Abdul Rahim² \\ ${ }^{1}$ Department of Syariah, Faculty of Religious Studies, Universiti Kebangsaan Malaysia, Bandar Baru Bangi, \\ Selangor, Malaysia \\ ${ }^{2}$ Faculty of Law, Universiti Kebangsaan Malaysia, Bandar Baru Bangi, Selangor, Malaysia \\ Correspondence: Wafaa' Binti Yusof, Department of Syariah, Faculty of Religious Studies, Universiti \\ Kebangsaan Malaysia, 43650 Bandar Baru Bangi, Selangor, Malaysia. Tel: 60-3-8920-1705. E-mail: \\ wafaa.yusof@yahoo.com
}

Received: January 26, 2014 Accepted: March 25, 2014 Online Published: April 29, 2014

doi:10.5539/ass.v10n10p95 URL: http://dx.doi.org/10.5539/ass.v10n10p95

\begin{abstract}
The non-conformity in the use of the terms concerning children and their age in the Shariah criminal legal system in the states in Malaysia has given rise to legal conflict as well as causing difficulties in terms of the execution and enforcement of shariah legal crime and its procedures in each of the afore stated states. The existing laws show that there exists non-dissidence in determining the position of children which conflicts with syariah crime. The term young offender was duly provided in the shariah procedural enactment but not in states' shariah criminal law. Similarly, the term 'baligh' was defined and the position of non-baligh children was elucidated in the said law but not under the shariah procedural enactment. Hence, this articles serves to lay down the provisions of both enactments concerned and to compared them with the shariah criminal principles in terms of ascertainment of age and the position of children which are in conflict with the shariah criminal law through the ulama and Islamic fuqaha's standpoint. This approach was adopted to determine as to what extent are the distinctive provisions shariah-compliant. This article unmasks the lacunae on shariah criminal law in the states particularly those pertaining children, conflicting with shariah. This finding raises the possibility re-examination as to the existing provisions. The analysis depicts the fact that each 'baligh' provision is duly reinforced by the ulama and fuqaha's views which contribute to khilaf in this case. Correspondingly, the provision in shariah procedural enactments in Malaysia that a young offender is one who is not less than 10 years of age and not more than 16 years old is still very much debatable, considering the provisions on baligh. Thus, the detailed re-examination of the shariah criminal legal system pertaining children which conflicts with shariah criminal law is very much necessary for the justice of all of the parties concerned.
\end{abstract}

Keywords: age, young offenders, criminal responsibility, shariah laws, Malaysia states' shariah criminal laws

\section{Introduction}

The states shariah criminal legislations do not have jurisdiction on offences except in so far as conferred by the Ninth Schedule, List 2 of Federal Constitution of Malaysia. This legal jurisdiction only applies to those professing the religion of Islam, including the young shariah criminal offenders. The Child Act 2001 (Act 611) does not have jurisdictions over a child committing shariah offences notwithstanding it being the exclusive legislations for the children. Under the shariah criminal legislations, none of the states in Malaysia provides for a specific child act or enactment which is in conflict with the shariah criminal law. In fact, there are only few minimal provisions offered to young offenders, the status of the offences, and the criminal procedure governing them.

The definition of the term 'child' for example, is only found in some of the states shariah criminal enactments. The term child is mentioned in all the states shariah criminal enactment of Malaysia except in Perlis, Kedah, Kelantan and Pahang. These provisions are numbered differently and for instance section 51 for Shariah Criminal Offences Act (Federal Territories), Shariah Criminal Offences (State of Johor) Enactment 1997, and Criminal Offences (State of Penang) Enactment 1996; section 10 for Shariah Offences (State of Malacca) Enactment 1991, Shariah Criminal Offences (Selangor) Enactment 2004, and Shariah Criminal Offences (Sabah) Enactment 1995; section 4 for Crimes (Shariah) (Perak)Enactment 1992; section 43 for Shariah Criminal 
Offences (Selangor) Enactment 1995; section 63 for Shariah Criminal Offences (Taazir) (Terengganu) Enactment 2001 and section 48 for Shariah Criminal Offences (Sarawak) Ordinance 2001. Whilst the only provision that mentions the term 'child' in the shariah criminal procedure enactments is merely for name and address validation and again the sections' number involved is differed from one state to another. The term 'juvenile offenders' or 'young offenders' on the other hand are mentioned in section 2 of all the states' shariah criminal procedure enactments. The different terms of children causes conflicts in the implementation and enforcement of the shariah criminal law and shariah criminal procedure in all the states. These anomalies in the provisions lead to inconsistencies between the two legislations, i.e., the shariah criminal enactment and the shariah criminal procedure enactment, in determining the position of a young offender committing shariah offences.

\section{Relevant Legal Provisions Relating to Young Offenders in Malaysia}

Young offenders under the shariah criminal procedure enactment are different from young offenders as provided under the Criminal Procedure Code. A young offender pursuant to the Criminal Procedure Code is a person who has been convicted of an offence punishable by a fine or an imprisonment, of age eighteen years or more and under the age of twenty-one years. The Criminal Procedure Code has jurisdictions over cases involving young offenders and provides the same procedures for young offenders as the adult offenders in criminal case. The arrest, search, investigation, detention, charge and prosecution against them are no different from adult offenders. They are tried in the civil court instead of the court of children.

This is contrary to the definition of the term young offenders under the states' shariah criminal procedure enactment, which categorizes them as person above the age of ten years and under the age of sixteen. The anomalies in the usage and definition involving two different jurisdictions have caused confusion in the legal system in Malaysia. The Criminal Procedure Code has no jurisdiction against young offenders defined by the shariah criminal procedure enactment in most of the states in Malaysia. Young offenders as defined by the enactment in fact still fall under the category or definition of children under the Child Act 2001which is defined as "A child means a person of the age below eighteen years and is relevant to the criminal proceeding, which means a person who has reached the age where he or she is liable to any criminal act as stated under section 82 , Penal Code (Act 574)."

The shariah criminal procedure enactment in eleven states of Malaysia define young offenders as a person over the age of ten years and less than sixteen (Shariah Criminal Procedure (Federal Territories) Act 1997; Shariah Criminal Procedure (State of Johor) Enactment 2003; Shariah Criminal Procedure (State of Malacca) Enactment 2002, Shariah Criminal Procedure (Kelantan) Enactment 2002, Shariah Criminal Procedure (Pahang) Enactment 2002; Shariah Criminal Procedure (State of Penang) Enactment 2004; Shariah Criminal Procedure (Perak) Enactment 2004; Shariah Criminal Procedure (Sabah) Enactment 2004; Shariah Criminal Procedure (State of Selangor) Enactment 2003; Shariah Criminal Procedure (Terengganu) Enactment 2001; Shariah Criminal Procedure (Negeri Sembilan) Enactment 2003; Shariah Criminal Procedure (Sarawak) Ordinance 2001). Perlis is the only state that provides the term 'remaja' or 'youthful' in shariah criminal procedures enactment and defines it as a male or female person under the age of eighteen years (Enactment 7 Year 1993; Criminal Procedure in the Syarak (State of Perlis) Enactment 1991).Kedah does not provide for a definition for young offenders as there is no relevant provision with regards to baligh (puberty or adulthood) or mukalaf in shariah criminal law. Nonetheless, the law does provide one section on criminal procedures against a young offender (Shariah Criminal Procedure Enactment (State of Kedah) 1988).

The different definition given by the enactments to the age categories of offenders has caused inconsistencies in the enforcement of shariah criminal procedure legislation between the states and the judgments. For example, most of the states shariah criminal procedure enactments have the provisions those young offenders as those who are above the age of ten years and less than sixteen. Instead, Perlis provides young offender as a male or female under the age of eighteen years. Therefore, a seventeen year old offender who has committed a crime in Selangor, for example, will be tried as an adult, but it is not so in Perlis.

These anomalies are not only on the states shariah criminal procedure legislation but also between the criminal law legislations. Shariah criminal law provides term 'baligh' instead of 'young offender'. Baligh is defined as a child who has not yet attained the age of puberty. Inconsistencies between the provisions of the two legislations affect the implementation and enforcement of these laws under the states shariah legal and judicial system.

\section{Legal Provisions with Regards to Baligh (Puberty)}

The definition of baligh is provided in most of the states shariah criminal enactments, acts and ordinances, except for Kedah, Kelantan, Pahang and Perlis (Shariah Criminal Code (State of Kedah) Enactment 1988; 
Shariah Criminal Code (Amendment) (State of Kelantan) Enactment1987; Administration of the Religion of Islam and the Malay Custom of Pahang Enactment 1982; and Criminal Offences in the Syarak (Amendment) (State of Perlis) Enactment 2007). A general definition of baligh is "old enough according to shariah", is adopted in most legislations (Shariah Criminal Offences Act (Federal Territories) 1997; Shariah Criminal Offences Enactment 1997 of Johor; Criminal Offences Enactment (State of Penang) 1996; Shariah Criminal Enactment (Selangor) 1995; Criminal Offences Enactment (Taazir) (Terengganu) 2001 and Shariah Criminal Offences Ordinance of Serawak 2001) except the Perak enactment which uses the term "akil baligh" (Crimes (Shariah) (Perak) Enactment 1992) while the enactment of Negeri Sembilan exclusively defines baligh as a person who has reached the age of twelve years old according to qamariah years(Shariah Criminal (Negeri Sembilan) Enactment 2004). Meanwhile, Melaka and Sabah though do not provide the definitions of baligh, has established a level of certain age to be considered as the age of a non-baligh child (Shariah Offences (State of Malacca) Enactment 1991; Shariah Criminal Offences (Sabah) Enactment 1995). However, the establishment of age provisions between these two states are different. Melaka establishes that a person under the age of fifteen qamariah years shall be presumed as a child or a non-baligh (Shariah Offences (State of Malacca) Enactment 1991) whilst Sabah provides a child as a person under the age of twelve qamariah years (Shariah Criminal Offences (Sabah) Enactment 1995).

Terengganu is the only state that has provided not only the definition of baligh but also the definition of mukalaf in the enactment. However, there are two different definitions of 'mukalaf' in two Terengganu shariah criminal laws even though one of them has not yet been enforced. Shariah Criminal Offences (Takzir) (Terengganu) Enactment has defined mukalaf as "a Muslim who has attained the age according to syarak, of good state of mind, and is not deaf and blind" (2001) and the Shariah Criminal Offence (Hudud and Qisas) (Terengganu) Enactment also defines it as "a person who has attained the age of 18 years and of good state of mind" (2002).

In summary, there are four different provisions of baligh in the states shariah criminal laws as below:

a) baligh in general term, indicating a child has attained the age of puberty;

b) baligh when a person has attained the age of twelve qamariah years;

c) baligh when a person is older than fifteen years; and

d) baligh and of good state of mind, a person who has come of the age of puberty.

\section{The Position of the Acts of a Non-Baligh Child According to Shariah}

The act of a non-baligh child is provided in several states shariah criminal enactments except for Kedah, Kelantan, Perlis and Pahang. A criminal act is not considered as a criminal offence pursuant to the provisions. The provisions make it clear that there is nothing wrong or blameworthy whatsoever incurred by a child who is a non-baligh. It is clarified in section 51, Shariah Criminal Offences (Federal Territories) Act, Shariah Criminal Offences (State of Johor) Enactment 1997 and Criminal Offences (State of Penang) Enactment 1996; Section 10, Shariah Offences (State of Malacca) Enactment 1991, Shariah Criminal (Negeri Sembilan) Enactment 2004 and Shariah Criminal Offences (Sabah) Enactment 1995; Section 4, Crimes (Shariah) (State of Perak) Enactment 1992; Section 43, Shariah Criminal (Selangor) Enactment 1995; Section 63, Criminal Offences (Taazir) (Terengganu) Enactment 2001; Section 48, Shariah Criminal Offences (Sarawak) Ordinance 2001. These provisions take into account the views of the jumhur ulama (majority Muslim scholars) who have stressed the baligh requirement as one of the perpetrators of crimes in order to create a moral element. The existence of a moral element determines whether an act is considered a crime or not apart from material and legal elements. The element of material is said to exist having pre-set intention or idea to commit a crime carried out in practice either through positive violation of prohibitions or negatively non committing something that was told (Alwi Haji Abdul Rahman, 1999; ${ }^{\mathrm{c} A b d u l ~ Q a d e r}{ }^{\mathrm{c}}$ Audah, n. d.).

A person who has not attained baligh or showing development deficient in the nature and physiological conditions of physical and intellectual growth according to al-Thaclabiy is to be considered as a child (al-Thaclabiy, 1999). The evidence of baligh according to several Muslim jurists indicates a child that is physically and mentally fully grown or developed. Al-Amidiy explains that the Islamic law has set baligh as a sign of puberty trait of a child's intellect maturity and wisdom (n. d.). The nature of baligh, according to Ibn ${ }^{c}$ Abidin, marks the end of adolescent and the beginning of adulthood, placing full responsibility on their every conduct (2000). The nature of baligh entitles a person to become taklif (person who meets the legal prerequisites to become a mukallaf) set by Allah Al-Mighty and to be accepted and recognized as a mukalaf. Baligh demonstrates perfect development of mind and wisdom, and a person's mind is central to the provision of taklif (Sabahiy, 2008). 
The opinions of the jumhur ulama differ from the opinions of some al-Shafii's jurists which view that the criminal acts committed by a child is to remain a crime (al-Suyutiy, 2003). However, they will not be punished as an adult under qisas and hudud punishment since they are not mukalaf. The criminal punishment of qisas and hudud is too harsh (Ibn ${ }^{\mathrm{C}} \mathrm{Abidin}, 2000$; Ibn Qudamah, 2005; al-Shiraziy, n. d.) on a child and should not be imposed against children who are not yet mukalaf. Punishment for the convicted children will be in the form of ta'dib ('Audah, n. d.; Ibn Farhun, 1995) involving civil responsibility similar to compensation and diah (Ibn ${ }^{c}$ Abidin, 2000; ${ }^{c}$ Audah, n. d.). The punishment of $t a^{\prime} d i b$ (rehabilitation) falls under the category of takzir. Therefore, a mumaiyyiz child who can think but still lacking wisdom entitles to receive a ta'dib punishment instead of criminal punishment.

Thus the children cannot be considered as committing an offence that can be punished with qisas, hudud or takzir because they are not mukalaf (al-Kasaniy, 2000; al-Bayjuri, 1983; al-Mahalliy, 1956; al-Sharbiniy, 1994) or not yet baligh and immature in intellectual mind (al-Kasaniy, 2000; Ibn Rusyd, 1999) despite their confession of admitting to the crime (al-Kasaniy, 2000). Children are not able to choose between the good and bad as well as understanding the impact of their conduct due to their immaturity. In fact they are not to be called convicts because they have not committed any crime (al-Kasaniy, 2000; al-Bayjury, 1983; al-Mahalliy, 1956; al-Sharbiniy, 1994).

Four different provisions on baligh discussed earlier in the states' shariah criminal laws entail diverse implications in the implementation of criminal justice against child offenders despite the similar provisions for the states' shariah criminal procedure laws. For example, a fourteen year-old child is considered a non-baligh under the Shariah Offences (State of Malacca) Enactment 1991. His criminal act is not considered as an offence and no legal action should be taken against him. Whilst a child of such age in Selangor will only be considered to have committed a criminal offence if he or she has attained baligh as section 43 of Shariah Criminal Enactment (Selangor) 1995 stated that "nothing wrong whatsoever incurred by children who have not attained puberty." Meanwhile in Sabah the same crime committed by a child of the same age is considered to have committed a criminal offence because he or she would be considered a baligh under the Sabah shariah criminal law as section 10 of Shariah Criminal Offences (Sabah) Enactment 1995 elaborates that a person of age less than twelve qamariah years will be considered as a non-baligh. However, those states' shariah criminal procedures enactment apply the same set of procedures against young offenders over the age of ten years and less than sixteen years as practiced by most states.

\section{Children Are Considered as Baligh When They Attain the Age of Twelve Qamariah Years}

Criminal acts committed by children under the age of twelve years are not considered as crimes because they are non-baligh. This has been provided for in the shariah criminal enactments of Negeri Sembilan and Sabah. The shariah criminal procedure laws in these two states also provide procedures for young offenders of age over ten years and less than sixteen years. Assuming an eleven year-old child has committed a shariah crime that falls under these two enactments, the act is not a criminal offence. Hence, the necessity to have a provision for the shariah criminal procedure for a ten year-old is questionable because obviously the act committed by an eleven year-old child is not considered as a criminal offence pursuant to the shariah criminal enactments of Melaka and Negeri Sembilan, whilst the process of pre-trial, trial and punishments are executed when there is a criminal offence. Even, the opinion of mazhab (sect) adopted by the two states can also be argued because the four widely referred mazahib (sects) do not indicate the perception of baligh begins after the age of twelve years. The perception of baligh is used only in the absence of visual physiological signs between the ages of fifteen and eighteen.

Sentences (' $\left.{ }^{c} u q u b a h\right)$ can only be carried out on a person who has attained baligh according to the three Muslim mazahib (al-Mawardiy, 1994) besides Hanafiyyah and some of the al-Shaficiyyah (al-Sharbiniy, 1994). The situations of children between twelve to fourteen years of age, do these provisions apply? This issue can be questioned. The laws in fact are clearly in contradiction with the holding of the four highly referred Muslim mazahib of ahlu al-sunnah wa al-jamac ah that have been highly referred to in many shariah law makings in the event of lacunas in the states Islamic legislations as stated in the enactment's indemnity clause which is prescribed under section 230 or 233 of the states' shariah criminal procedure enactments. The law of syarak according to the meaning given in the statute of the criminal law and shariah criminal procedure as the syarak law pursuant to mazhab Shafii, or pursuant to any one of mazhab Maliki, Hanafi or Hanbali, or Islamic law pursuant to any recognized mazhab or Islamic law in accordance with any legal mazahib giving preferences to the mazhab Shafii.

It can be concluded that the perceived baligh at the age of twelve years is not based on any of the highly referred 
sects in the shariah law in Malaysia. The assumption is quite in line with the ruling of section 83, Penal Code provisions, which stipulates that twelve year old children are liable for their criminal conduct without conditions. Nonetheless, these two legislations are placed in two different jurisdictions that cannot be reconciled.

\section{Perception of Children as Baligh When Reaching the Age of Fifteen Years and Above}

The shariah criminal enactment of Melaka (1991) indicates someone under the age of fifteen years is considered a non-baligh. Description in the provisions states that "a person whose age is less than fifteen qamariah years should be considered as a non-baligh." Criminal behaviours of children under the age of fifteen years pursuant to the shariah criminal enactment are not deemed to be an offence because the child is considered as a non-baligh. The enactment of this provision clearly takes into account the baligh ruling through age estimation. This would mean that children who reach the age of fifteen years are considered to have attained the age of puberty when there are no signs of physiology.

${ }^{\mathrm{c}}$ Abdul Qader ${ }^{\mathrm{c}}$ Audah explains that, a dream which has become the standard benchmark for puberty from Islamic viewpoint will usually occur before the age of fifteen years. If the child has not had a dream but has attained the age of fifteen years, this can be said as a deficiency in terms of fitrah, nonetheless this does not mean a weakness of the mind (n. d.). Children over the age of fifteen years, according to Muhammad Abu Zahrah, can be considered baligh due to their ability to distinguish between good and bad and to make choices between the two acts (n. d.). Al-Zaila ${ }^{c}$ iy asserts the same stance and holds on to the hadith by Ibn ${ }^{\mathrm{c}}$ Umar when requesting permission from the Prophet s.a.w (peace be upon him) to fight the battle of Uhud but was turned down by the Prophet s.a.w., and he was then just fourteen years old. However, permission was granted later in the battle of Khandak when he was merely fifteen years old (n. d.).

Imam Nawawiy, resting upon the same hadith, asserts that baligh is the age that makes an individual a Rashid (matured person) from a legal point of view and therefore the punishment for adult offenders is compelled on the individual. The age for baligh to which he refers to is fifteen years as stated in the hadith. Similarly, the narration from ${ }^{\mathrm{C}}$ Umar ibn ${ }^{\mathrm{c}} \mathrm{Abdul}{ }^{\mathrm{c}} \mathrm{Aziz}$ upon hearing the news about Ibn ${ }^{\mathrm{C}} \mathrm{Umar}$ has said that the age of fifteen years is the limit between adolescent and adulthood (al-Sijistaniy, 1952).

The views put forward by the companions and Muslim jurists clearly support the age ruling for baligh as fifteen years old. The opinions however entail different impacts. The views expressed by ${ }^{\mathrm{c}} \mathrm{Abdul}$ Qader ${ }^{\mathrm{c}} \mathrm{Audah}$, Muhammad Abu Zahrah and Al-Zaila ${ }^{\mathrm{c} i y}$ do not perceive the age fifteen years as the baligh age turning a child into becoming an adult. Whilst opinions and statements by Imam Nawawiy and ${ }^{\mathrm{c}}$ Umar ibn ${ }^{\mathrm{c}} \mathrm{Abdul}{ }^{\mathrm{c}} \mathrm{Aziz}$ are of the opposite. This impact is even more apparent when associating it with the criminal procedure that applies to a child. The Shariah Criminal Procedure Enactment of Malacca, like any other states, only has provisions for young offenders over the age of ten years and less than sixteen years. Thus, is it necessary to provide for criminal procedures against young offenders age above ten years if a criminal act of a child age below fifteen years is not considered as a criminal offence according the Shariah Criminal Enactment in Malacca, whilst the process of pre-trial, trial and punishment were enforced when there is a criminal offence?

In fact, the need for a specific provision for a shariah legal criminal procedure for young offenders is also questionable if the views of Imam Nawawiy and ${ }^{c}$ Umar Ibn ${ }^{c}$ Abdul ${ }^{c}$ Aziz were taken into account. In other words, young offenders under the age of fifteen years shall not be considered as committing a criminal act based on the state's shariah criminal enactment. Meanwhile, young offenders aged fifteen years are already considered as adults and are subject to all procedures for adult criminal offenders. Therefore again, it is deemed wise for reference to be made to the arguments by ${ }^{\mathrm{C}}$ Abdul Qader ${ }^{\mathrm{c}}$ Audah, Muhammad Abu Zahrah and al-Zaila ${ }^{\mathrm{c}}$ iy.

Reference to the Muslim jurists' arguments still does not disprove of weaknesses in the provisions of the shariah criminal law and criminal procedure. The ruling of age fifteen years as baligh is applied only in the absence of visual physiological signs as an indication of baligh. Instead, Shariah Criminal Enactment in Malacca has set children starting the age of fifteen qamariah years as baligh irrespective of any physiological indication. Thus, children between the ages of nine to fourteen years who commit a crime under the state's criminal enactments will not be punished even if they already have menstruation or dreams indicating baligh since the criminal act is not deemed to be a criminal offence. These conflicts with the Islamic law and violation of the principles of justice can be said to have occurred here because baligh is considered as the beginning of one's responsibility against any criminal act in accordance with the Islamic law and the criminal acts they have committed shall be judged accordingly. The criminal responsibility is not, however, to be entirely a taklif on a baligh child except until the child attains the age of rusyd.

The ruling of fifteen years of age as the onset of puberty in the Shariah Criminal Enactment of Malacca coincides with the opinion of the mazahab (sects) in reference. However, the ages are inconsistent with the 
Shariah Criminal Procedures Enactment and this has caused confusion in the implementation of the shariah criminal procedure legislation.

\section{Children Are Considered Baligh Based on the Determination of Fixed Age}

Disclosure of puberty is determined by physiological signs or calculation of maximum age for baligh. Both of these conditions involve disagreement from the Muslim jurists. Therefore, the states which general provisions of baligh age in their shariah criminal laws are in line with the views of some Muslim jurist. According to the opinion of Imam Abu Zahrah (n. d.), al-Qurtubiy (2008), Ibn ${ }^{\text {c} A b i d i n ~(2000), ~ a l-A m i d i y ~(1984) ~ a n d ~ a l-S a r a k h s i y ~}$ (1997), the disclosure of physiological signs indicates the end of childhood and the proof of physical development and maturity of the child's mind. This provision also takes into account the age of puberty according to the estimation of age in the absence of physiological signs outwardly. There are three main opinions in this matter. The first opinion is as discussed in the above sub-heading, i.e. the age of fifteen years. Whilst, the second opinion from Imam Abu Hanifa stipulates an adulthood age for boys is eighteen years and the girls seventeen years (Ibn ${ }^{\mathrm{C}}$ Abidin, 2000).The third opinion from Imam Malik sets the age eighteen years for both boys and girls ( ${ }^{\mathrm{C}}$ Audah, n. d.).

The same question lingers in mind when assuming a nine year old girl who has surpassed menstruation, or a ten year old boy who has had a dream, commits a shariah criminal offence. The child's acts, according to the provision of shariah criminal enactment of the states, is considered as a criminal offence because he or she has attained baligh and has begun to bear criminal responsibility although not fully. However, the question is, how do the religious enforcement officers and the judges handle this case, whilst the enactment of shariah criminal procedures only provide procedures for those age more than ten years and less than sixteen years old?

This provision does not pose any conflicts with the Islamic law and furthermore opens a wider scope in varying references and arguments of the Muslim jurists. In reality, this phenomenon can cause ambiguity in the application and enforcement of the states shariah criminal law and criminal procedure involved.

\section{Baligh and Rusyd as Indications of the Age Criminal Responsibility}

Perak is the only state that requires not only baligh but also rusyd for children considered to be committing a crime. This provision is consistent with the view of most jurists in their discussion of the conviction and execution of the shariah criminal penalties.

Ahmad Fathiy Bahnasiy (1984) and al-Kasaniy (2000) stress that a baligh child undeniably is a taklif but it is not complete until the child's mind has fully developed or reached the stage of rusyd (maturity). Similarly, al-Tusiy mentions that children who reach the age of puberty partially fulfill the mukalaf requirements and one of the conditions as a mukalaf is of developed mind and understanding khitab Allah. Puberty and mature understanding according to Mohammad ${ }^{c}$ Ali Husseiniy are parts of the requirements to qualify a person to become a person who has full capacity to perform in addition to two other conditions, namely the ability to understand and making choices (2011). Al-Zaila ${ }^{\mathrm{c}}$ iy and al-Sharbiniy write that both characters equip a person with the eligibility condition for sentences and punishments and set conditions for taklif (1994). They are solely responsible for every act of their crime, and the punishment and criminal legal procedure are to be imposed on them as adults.

A person's mature mind however is something that is beyond human ability to determine accurately because maturity depends on various different factors for each individual. As previously stated by al-Amidiy and al-Sarakhsiy, that the completeness of physical growth through physiological signs indicates complete development and maturity of minds. There's no denying that physiological signs is a relative indication of a child's baligh. But these visual signs are inconsistent in determining the end of adolescent and the beginning of adulthood or the stage of rusyd (Salem, 2010).

Findings from the survey by Deborah Yurgelun-Todd, an euro psychology expert from Harvard Medical School, have shown that teenagers evaluate information and understand implications and consequences in a different manner from adults. Therefore, a person who is physically mature does not necessarily mean also mature in intellect (2004). She also explains that teenagers often respond to things and actions based on instinct rather than considerations. Ruben C. Gur adds that the findings produced by Deborah gives a new understanding of the delinquents. He says that part of the brain that controls impulsive behaviour, judgment, future planning, possible consequences and several other features does not stop the maturity process until the age of early 20 s and 21 or 22 years, which is close to the age of biological maturity (2004). The findings of this study illustrate that the human maturity process begins with physical maturity then only followed by mature minds. Physical maturity and minds clearly do not occur simultaneously. A child who has come of age or baligh is therefore is more apt to be considered a mature in terms of physical. Their minds grow slowly toward maturity and vary for each individual. 
No doubt there is the possibility that physical maturity and common sense grow simultaneously, but in isolated cases. Al-Rusyd in Islamic jurisprudence law may occur concomitantly with baligh, and can also occur later. It varies between each individual depending on a child's physical and mental development, nutrition, environment, climate, education, experience, and many more. Therefore, the provisions of the shariah criminal law of Perak can be considered as too rigid and confusing when the existence of offence is implicated only after a child is a baligh and of developed mind, whilst according to the Islamic law a person's criminal responsibility begins when he or she reaches baligh age although the child's mind is still not fully developed and immature.

Baligh and developed mind are the two maximum age criteria for children as required by the Muslim jurists. A child's adulthood begins at this maximum age and this varies according to the opinion of the Muslim jurists which includes the age of fifteen, seventeen and eighteen years. The provision related to 'akil baligh (puberty)' in Perak Criminal Enactment (Shariah) is uncertain if it follows any of the Muslim jurists' opinions. There is no provision defining the Islamic law and the provisions of indemnity clause in Perak Criminal Enactment (Shariah). The Administration of the Religion of Islam (Perak) Enactment however defines Islamic law as "the Islamic Law according to Shafii or any one of the sects of Hanafi, Maliki or Hanbali." This definition gives bigger allowance in the determination of baligh age and this phenomenon can lead to uniformity in the implementation of the shariah laws in Perak relating to child offenders.

Shariah Criminal Procedures (Perak) Enactment allocates for age more than ten years and less than sixteen years for youthful offenders. This provision, like provisions in other states, clearly is not consistent with the states shariah criminal laws. Analysis on the consistency between the opinions of the jurists with the existing provisions shows the two conflicting questionable issues. First, children of age fifteen years and which is in conflict with the shariah criminal laws are considered as baligh by Imam al-Shafii, Imam Ahmad, Ibn Wahab (Sabahiy, 2008) and al-Zailaciy (n. d.), who have set fifteen as the maximum age for $b a l i g h$. They are considered as akil baligh and adult offenders' procedures are applicable to them. However, the criminal procedures for children over the age of fifteen years according to the Shariah Criminal Procedures (Perak) Enactment are under the legal provisions of the youthful offenders. Whilst, the second condition support the opinions of Hanafi and Maliki scholars who set seventeen and eighteen years as the maximum age for baligh without posing any confusion on implementation. They are considered as adult offenders and criminal procedures are rightly applicable on them. However, the position of a child over the age of sixteen years and which is in conflict with the shariah criminal law is being questioned. The child is considered as a non-baligh according to the jurists and they are not subject to legal procedures for adult offenders. Whilst, the procedures for youthful offenders under the enactment on the other hand are applicable to those below the age of sixteen years.

\section{Conclusion}

The ruling age for young offenders in the criminal procedure enactment and the determination of criminal behaviour of non-baligh children in the shariah criminal enactment which varies from one state to another is not actually contrary to law. Each provision has its own submissions and valid considerations as long as it is not contrary to the $q a t^{c} i y$ law. There are some scholars who set the maturity age for children once attaining the age of baligh, and there are scholars who perceive the age of fifteen to eighteen years in which criminal responsibility begins (Ibn Rusyd, 1999). In fact, there are scholars who view baligh age as not an indication of adulthood due to no showing of maturity until the children obtain maturity or attain the age of rusyd.

However, the ruling age for young offenders in the states' shariah criminal procedure enactment in Malaysia, as a person age not less than ten years and not more than sixteen years, can still be debated. The issue is, what is the difference between a child who has attained baligh at the age of nine years, more than ten years, less than sixteen years, and under the age of eighteen? Existing provisions indicate that baligh children with age more than ten years and less than sixteen years, (except for Perlis with age eighteen years and below), are subjected to the provisions. Baligh children at the age of nine years are not subjected to the provision because they are not young offenders as defined under the state enactments, whilst, according to Islamic law once a child is a baligh notwithstanding of the age, he or she falls under the taklif. Moreover, the condition of taklif is not purview from the term 'child' or 'youth' but upon the reaching of baligh and rusyd. On the other hand, the provisions of the shariah criminal procedure enactment of the states nowadays are the opposite.

Therefore, the writers are of the opinion that there are still rooms for shariah law makers in Malaysia to consider the maslahat as a whole in a holistic view taking into account the maslahat of the child offenders and the maslahat of the society in general. Several factors need to be considered, namely:

a) To set the ruling of young offenders under the relevant provision as child offenders. The measure aims to coordinate the use of the term not only among the states shariah laws, but also between shariah laws and civil 
laws. Furthermore, if they were deemed no longer a child, why the isolation of such provisions; as the boundary separating children and adults is baligh and rusyd.

b) To provide and coordinate a clearer definition of child offenders in all shariah criminal laws and shariah criminal procedures for the states, since there are still states that do not provide the definition of a child in their enactments but do provide for criminal procedures provisions for young offenders.

The authors also see merit with regard to the age of eighteen years as the maximum age for children. The merit is based on several reasons:

a) The stage of maturity or rusyd of a person varies and that it does not have a set bench mark. In fact, it cannot be considered in individuality but by looking at the prevalence norms influencing the children; and norms are usually dependence on many factors i.e. the community groups, geography, culture and many more. Thus, most legal provisions of Malaysia currently are with the norm that a child is defined as an individual under the age of eighteen.

b) The age of eighteen years is the maximum age for a baligh child according to the Hanafi sect and is one of the opinions strongly held and approved by the shariah legal system in Malaysia.

This ruling must not be considered in contravention of the Islamic law if the principles of maslahat and justice were to be considered. These measures in real sense have been implemented by the Perlis shariah criminal procedure law defining young offenders as a male or a female under the age of 18 years (Criminal Procedures in the Syarak (State of Perlis) Enactment 1991). Legal inconsistency in fact can lead to injustice to all respective parties including the offenders, victims of crimes, or society in general. In fact, this opens to the discretionary power of the judges and the religious enforcement officers raising possibilities of committing injustice and misuse of power. The power to accomplish ijtihad of the judges in deciding on sentences cannot be refuted but for the sake of justice for all, it is only wise to hold on to one consented opinion and to set for consistent and uniform provisions.

\section{References}

Abu Dawud, \& Al-Sijistaniy, S. I. A. (1952). Sunan Abu Daud, 4. Mesir: Mustafa al-Baabi al-Halabi.

Abu Zahrah, \& Muhammad. (n. d.). al-Jarimahwa al-uqubah fi al-figh al-Islamiy, al-jarimah. Kaherah: Dar al-Fikri al- ${ }^{\mathrm{c}}$ Arabiy.

Al-Bayjuriy, I. (1983). Hashiyah Ibrahim al-Bayjuriy, 2. Mesir: Darr al-Tiba ${ }^{\mathrm{c}}$ ah al-Kubra al-Misriyyah.

Al-Kasaniy, 'A. A. A. B. B. M. A. (2000). Kitab bada' $i^{c}$ al-sana ${ }^{c}$ f fi tartib al-sharaciy, 7. Beirut: Darr Ihya' al-Turath al- ${ }^{\mathrm{C}}$ Arabiy.

Al-Mahalliy, J. A. M. B. A. (1956). Sharhu al-minhaj al-talibin, 4. Kaherah: Mustafa al-Halabi.

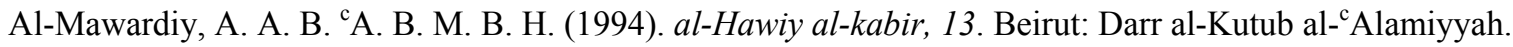

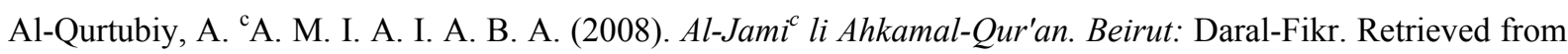
http://www.iidalraid.de/EnOfQuran/TafseerBooks//qurtby077.htm

Al-Sarakhsiy, M. B. A. B. A. S. (1997). Usul al-Sarakhsi, 1. Beirut: Darr Macrifah.

Al-Sharbiniy, M. B. A. (1994). Mughniy al-muhtaj ila mácrifati macaniy alfazi al-minhaj, 5. Beirut: Darr al-Kutub al- ${ }^{\mathrm{C}}$ Alamiyyah.

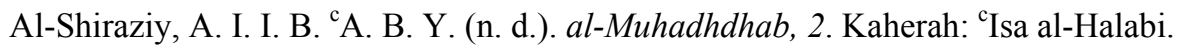

Al-Suyutiy, J. A. ${ }^{c}$ A. R. (2003). al-Ashbah wa al-nazair fi qawa ${ }^{c} i d$ wa furu ${ }^{c}$ fiqh al-shaficiyyah. Kaherah: Darr al-Salam.

Al-Tha ${ }^{c}$ albi, A. M. (1999). Figh al-lughah wa sir al- ${ }^{c}$ arabiyyah. Beirut: Darr al-Fikr al ${ }^{\mathrm{c}}$ Arabiy.

Al-Zaila ${ }^{c}$ i, F. A. (n. d.). Tabyin al-Haqai'q Sharh Kanz al-Daqa'iq. Mesir: Dar al-Kitab al-Islamiy.

Bahnasiy, M. F. (1984). al-Mas'uliyyatu al-janaiyyatu fi al-fiqh al-islamiy dirasah fiqhiyyah muqaranah. Beirut: Darr al-Shuruq.

${ }^{\text {c} A b i d i n, ~ I ., ~ \& ~}{ }^{c}$ Umar, M. A. I. (2000). Hashiyah radd al-mukhtar ala al-durr al-mukhtar, 6. Beirut: Darr Ma ${ }^{\mathrm{c}}$ rifah.

${ }^{\mathrm{C}}$ Audah, ${ }^{\mathrm{C}} \mathrm{A}$. Q. (n. d.). al-Tasyric al-jana'iy al-Islam muqaranan bi al-qanun al-wad'iy, 1. Beirut: Dar al-Kitab al- ${ }^{\mathrm{c}}$ Arabiy.

Criminal

Enactment

(Shariah)

(Perak).

(1992).

Retrieved

from 
http://www2.esyariah.gov.my/esyariah/mal/portalv1/enakmen/undang.nsf/listsphg?OpenForm

Criminal Procedure in the Syarak (State of Perlis) Enactment. (1991). Retrieved from http://www2.esyariah.gov.my/esyariah/mal/portalv1/enakmen/undang.nsf/listsphg?OpenForm

Criminal Procedures Code (Act 593). (2012). Selangor: International Law Books Services.

Farhun, I., \& Muhammad, B. A. I. B. 'A. B. A. B. (1995). Tabsirah al-hukkam fi usul al-aqdiyah wa manahij al-ahkam, 2. Beirut: Darr al-Kutub al- ${ }^{\mathrm{C}} \mathrm{Ilmiyyah}$.

Gur, R. C. (2002). Ph.D. Declaration of Ruben C. Gur. Patterson v. Texas. Petition for Writ of Certiorari to US Supreme Court. J. Gary Hart, Counsel. Retrieved from http://www.abanet.org/crimjust/juvjus

Husseiniy, ${ }^{\mathrm{C}} \mathrm{A} .$, \& Mohammad. (2011). al-Taklif al-shar ${ }^{\mathrm{i}}$ wa shurutuhu. al-Majlis al-Islami al- ${ }^{\mathrm{C}}$ Arabi. Retrieved from http://arabicmajlis.com/?id=1133

Ortiz, A. (2004). Cruel and unusual punishment: The juvenile death penalty, adolescence, brain development and legal culpability. Washington: Juvenile Justice Centre, American Bar Association. Retrieved from http://www.abanet.org/crimjust/juvjus

Qudamah, I., \& Al-Maqdisiy, A. M. ${ }^{\mathrm{C}}$ A. B. A. B. Q. M. (2005). al-Mughniy. Al-Riyadh: Darr ${ }^{\mathrm{c}}$ Alim al-Kutub.

Rahman, A. H. A. (1999). Juvenile crimes according to Islam. Selangor: Dewan Bahasa dan Pustaka al-Amidiy, ${ }^{\mathrm{c}}$ Ali bin Abi ${ }^{\mathrm{c}}$ Ali bin Muhammad. (1404H/1984M). Al-ihkam fi usul al-ahkam, 1. Beirut: Darr al-Kutub al- ${ }^{\mathrm{C}}$ Ilmiyyah.

Rusyd, I., \& Rusyd, A. A. M. B. A. B. M. B. A. B. (1999). Bidayah al-mujtahid wanihayah al-muqtasid, 2. Beirut: Darr Macrifah.

Sabahiy, M. R. (2008). Jara'im al-ahdath fi al-sharic ati al-islamiyyah, al-musykilatu wa al-ilaj, dirasatun fiqhiyyatun tarbawiyyatun. Dimashq: Darr al Nawadir

Salem, A., \& Ahmed, 'A. (2010). Huquq al-tifli fi al-Islam, al-huquq wa al-hajati min al-nutfati ila al-marahiqah. Retrieved from http://uqu.edu.sa/page/ar/112048

Shariah Criminal (Negeri Sembilan) (Amendment) Enactment. (2004). Retrieved from http://www2.esyariah.gov.my/esyariah/mal/portalv1/enakmen/undang.nsf/listsphg?OpenForm

Shariah Criminal Offences (Federal Territories) Act. (1997). Retrieved from http://www2.esyariah.gov.my/esyariah/mal/portalv1/enakmen/undang.nsf/listsphg?OpenForm

Shariah Criminal Offences (Sabah) Enactment. (1995). Retrieved from http://www2.esyariah.gov.my/esyariah/mal/portalv1/enakmen/undang.nsf/listsphg?OpenForm

Shariah Criminal Offences (Sarawak) Ordinance. (2001). Retrieved from http://www2.esyariah.gov.my/esyariah/mal/portalv1/enakmen/undang.nsf/listsphg?OpenForm

Shariah Criminal Offences (Selangor) Enactment. (1995). Retrieved from http://www2.esyariah.gov.my/esyariah/mal/portalv1/enakmen/undang.nsf/listsphg?OpenForm

Shariah Criminal Offences (State of Johor) Enactment. (1997). Retrieved from http://www2.esyariah.gov.my/esyariah/mal/portalv1/enakmen/undang.nsf/listsphg?OpenForm

Shariah Criminal Offences (State of Penang) Enactment. (1996). Retrieved from http://www2.esyariah.gov.my/esyariah/mal/portalv1/enakmen/undang.nsf/listsphg?OpenForm

Shariah Criminal Offences (Taazir) (Terengganu) Enactment. (2001). Retrieved from http://www2.esyariah.gov.my/esyariah/mal/portalv1/enakmen/undang.nsf/listsphg?OpenForm

Shariah Criminal Procedure (Kelantan) Enactment. (2002). Retrieved from http://www2.esyariah.gov.my/esyariah/mal/portalv1/enakmen/undang.nsf/listsphg?OpenForm

Shariah Criminal Procedure (Negeri Sembilan) Enactment. (2003). Retrieved from http://www2.esyariah.gov.my/esyariah/mal/portalv1/enakmen/undang.nsf/listsphg?OpenForm

Shariah Criminal Procedure (Pahang) Enactment. (2002). Retrieved from http://www2.esyariah.gov.my/esyariah/mal/portalv1/enakmen/undang.nsf/listsphg?OpenForm

Shariah Criminal Procedure (Perak) Enactment. (2004). Retrieved from http://www2.esyariah.gov.my/esyariah/mal/portalv1/enakmen/undang.nsf/listsphg?OpenForm

Shariah Criminal Procedure (Sabah) Enactment. (2004). Retrieved from 
http://www2.esyariah.gov.my/esyariah/mal/portalv1/enakmen/undang.nsf/listsphg?OpenForm

Shariah Criminal Procedure (Sarawak) Ordinance. (2001). Retrieved from http://www2.esyariah.gov.my/esyariah/mal/portalv1/enakmen/undang.nsf/listsphg?OpenForm

Shariah Criminal Procedure (State of Johor) Enactment. (2003). Retrieved from http://www2.esyariah.gov.my/esyariah/mal/portalv1/enakmen/undang.nsf/listsphg?OpenForm

Shariah Criminal Procedure (State of Kedah) Enactment. (1988). Retrieved from http://www2.esyariah.gov.my/esyariah/mal/portalv1/enakmen/undang.nsf/listsphg?OpenForm

Shariah Criminal Procedure (State of Malacca) Enactment. (2002). Retrieved from http://www2.esyariah.gov.my/esyariah/mal/portalv1/enakmen/undang.nsf/listsphg?OpenForm

Shariah Criminal Procedure (State of Penang) Enactment. (2004). Retrieved from http://www2.esyariah.gov.my/esyariah/mal/portalv1/enakmen/undang.nsf/listsphg?OpenForm

Shariah Criminal Procedure (Terengganu) Enactment. (2001). Retrieved from http://www2.esyariah.gov.my/esyariah/mal/portalv1/enakmen/undang.nsf/listsphg?OpenForm

Shariah Criminal Procedures (State of Selangor) Enactment. (2003). Retrieved from http://www2.esyariah.gov.my/esyariah/mal/portalv1/enakmen/undang.nsf/listsphg?OpenForm

Shariah Offences (State of Melaka) Enactment. (1991). Retrieved from http://www2.esyariah.gov.my/esyariah/mal/portalv1/enakmen/undang.nsf/listsphg?OpenForm

\section{Copyrights}

Copyright for this article is retained by the author(s), with first publication rights granted to the journal.

This is an open-access article distributed under the terms and conditions of the Creative Commons Attribution license (http://creativecommons.org/licenses/by/3.0/). 